\title{
BUILDING UP SISU, A NORDIC CULTURAL CONSTRUCT FOR THE COMPREHENSIVE DEVELOPMENT OF HEALTH AND HARMONY
}

\author{
Birutė Strukčinskienè \\ Klaipèda University (Lithuania)
}

\begin{abstract}
The Finnish concept of sisu is a phenomenon in Nordic culture that has existed for 500 years in the Finnish nation. This cultural construct, a kind of lifestyle, a kind of ideology of life, enables the development of a persevering, balanced, enduring, resilient, healthy and harmonious personality. The sisu phenomenon inspires one to persevere, and to fight for success despite difficulties, even when it seems that the limits of human power have already been reached. The Nordic cultural construct of $s i s u$ has been linked with mental toughness and resilience, and good physical and mental health. There are elements that help to develop sisu in the individual and in society. They include the mindfulness of nature, physical activity, positivity, relaxation and recreation, withdrawal and stepping back, task fragmentation, leaving the comfort zone, and reward for completing a task. All of these are important elements for developing perseverance and inner strength, or sisu.

KEY WORDS: Nordic countries, Finland and sisu, cultural construct, perseverance, endurance and resilience, health and harmony, promotion of health and well-being.
\end{abstract}

\section{Anotacija}

Suomiškasis sisu yra šiaurietiškosios kultūros fenomenas, suomių tautoje gyvuojantis 500 metų. Sisu kultūrinis konstruktas - tai savitas gyvenimo būdas, ideologija, leidžianti išsiugdyti atkaklią, darnią, ištvermingą, atsparią, sveiką ir harmoningą asmenybę. Sisu įkvepia ištverti, kovoti siekiant sėkmès nepaisant sunkumų, net kai atrodo, kad žmogaus jėgų ribos jau pasiektos. Šiaurietiškasis sisu siejamas su psichikos tvirtumu ir atsparumu, puikia fizine ir psichikos sveikata. Individo ir visos visuomenès ugdymas sisu dvasia - tai sąveika su gamta, gamtos terapija, fizinis aktyvumas, pozityvumas, poilsis ir rekreacija, atsiribojimas ir atsitraukimas, užduoties suskaidymas, patogumo zonos palikimas ir apdovanojimas pasiekus tikslą. Visi šie elementai, ugdant atkaklumą, ištvermingumą, vidinę jègą, sisu, yra svarbūs.

PAGRINDINIAI ŽODŽIAI: Šiaurès šalys, Suomija, sisu, kultūros konstruktas, ištvermingumas, atkaklumas, atsparumas, sveikata, darna, sveikatos stiprinimas, gerovès užtikrinimas.

DOI: http://dx.doi.org/10.15181/tbb.v87i2.2323

\section{Introduction}

The high mortality rates in Lithuania from external causes, intentional injury, suicide, poor mental health, stress and insecurity, and insufficient attention being paid to a healthy lifestyle, encourage the search for ways and possibilities of promoting health and well-being. 
In contrast, Lithuania's close neighbour Finland stands out with its low mortality and morbidity rates. For the fourth year in a row, Finland has recently been rated as the happiest country in the world. In addition, according to social and environmental indicators, it is the most progressive, as well as the most stable, the safest, and the freest (along with Sweden and Norway) state on the planet (Helliwell, 2021; Pantzar, 2018a). Therefore, it is important to study Nordic culture, phenomena of the unique lifestyle, cultural constructs and experience, and to apply good practices in other countries.

The ideology of life, well-being and quality of life, along with the interaction between lifestyle and health (physical, mental, emotional, social), encourage the exploration of various cultural constructs. Health-nature-human dimensions, the perception of health and harmony, welfare, well-being, and healthy behaviour are issues of research interest in different cultures. In the historical context of the neighbouring Nordic countries, the Danes focused on the essence of happiness in hygge and lykke, the Swedes emphasised the importance of balance in life through the concept of lagom, and the resilient and hard-working Finns were famous for five centuries for their sisu phenomenon (Wiking, 2017a; 2017b; Dunne, 2012; Lahti, 2014; 2019).

Researchers who have studied the cultural characteristics and aspects of the Nordic countries have paid special attention to the original phenomenon of sisu as a unique Finnish cultural lifestyle, a kind of ideology of life (Hicks, Tokoi, 1959; Goodrick, 1960; Lander, 1991; Aho, 1994; Lucas, 2002; Tramaa, 2007; Dahlgren, Nurmelin, 2007; Brueggeman, 2008; Pankola, Gronska-Turunen, 2010; Sinkkonen, 2013; Lahti, 2014; Amato-Henderson et al., 2014; Velazquez, 2014; Duckworth, 2016; Pantzar, 2018a; 2018b; Nylund, 2018; Adamczewski, Obrebska, 2018; Lahti, 2019; Etherington, 2019). Perseverance, determination, fearlessness, extraordinary endurance, resilience, grit, bravery, courage, resoluteness in the face of adversity, and energy are used to explain the concept of sisu. This Finnish phenomenon and cultural construct is associated with mental toughness, and strong physical, mental and social health.

The issue of searching for a suitable lifestyle model and the desire for a healthy, safe, sustainable, harmonious, balanced and perfect lifestyle are topical. The development of a mental and physical balance based on cultural practices is becoming important. The Baltic States are increasingly interested in the national experience of their closest neighbours, the Nordic countries, and the constructs of Nordic culture.

The aim of the study is to explore the Nordic cultural construct sisu for the comprehensive development of health and harmony. 


\section{Methods}

The Nordic cultural construct was investigated in a qualitative study using a hybrid methodology. The analysis of scientific literature, the analysis of discourse (the oral discourse and the analysis of conversation), round-table discussions, the analysis of experience, and elements of ethnography were applied. Search tools, platforms, social networks such as the PubMed database, the information submission system Google Scholar, and the complex search platform ResearchGate were used.

The descriptive method, generalisation and systematisation were applied. There were individual talks and round-table discussions. Memos were used; according to J. Aleknavičienè et al. (2020), memos are a diary of research planning and execution, in which notes, questions, ideas and reflections related to the research are recorded (Aleknavičiene, 2020). The memos recorded the analysis of insights, experience, reflections and phenomenon of the project participants (members and leaders of the scientific, health, medical and social sciences community, and policy-makers from the local government sector). The study participants not only had experience of cultural and ethnographic life, but also the competencies to transmit systematic information from scientific positions.

\section{Results and discussion}

2.1. Nordic Identity: The Finnish people, lifestyle and equality, and the Finnish cultural identity

When looking at the Finnish cultural model, it has been observed that the Finns have excellent self-control, concentration, diligence, responsibility, and a sense of duty. The people of this nation are distinguished by their ability to remain calm and wise in the face of a problem, obstacle or surprise. Important decisions are made on the basis on rationality, avoiding recklessness and sensuality. The Finnish people have a sensitive and impressive connection with nature, preferring naturalness, ecology and minimalism in the pursuit of a balanced personality (Nylund, 2018; Pantzar, 2018). The country's high achievements make it famous in the fields of education, technology, digital health sciences, achievements and progress in the contexts of people's quality of life, safety, culture and humanism.

Gender equality has played an important role at a national level in Finland for 140 years (Ministry of Social Affairs and Health, Finland, 2020a; 2020b). In the context of the Finnish identity, there is a significant component of equivalence, 
maintaining gender equality while avoiding both patriarchal and matriarchal denigration, humiliation and exploitation. This can be seen from the close environment and the level of family relations, to positive examples at the national (government and presidential) level. Finnish families are distinguished by gender equality, the division of labour and the balance of responsibilities between men and women, equal relationships, and equality in the household. Time alone is important in constructing parenthood, as 'being alone' provides opportunities for independent leisure, relaxation and renewal, feeling strong, and enjoying personal time. There are three areas in the daily life of Finnish spouses: family life, couple life, and individual personal life (Nylund, 2018; Böök, Mykkänen, 2019). It should be noted that in an individual's personal life, personal time is intended for respite, rest and the restoration of personal harmony (Böök, Mykkänen, 2019). Finnish society promotes gender equality at home. The logistics of everyday life can be stressful, despite the equality in personal relationships. Thus, the equal sharing of activities and work, and the discussion of undisclosed expectations, praise and encouragement, reduce tension and open up opportunities for smoother communication (Nylund, 2018). It is very important for Finns to treat the contribution of men and women to the home environment equally.

The Finnish cultural identity is revealed through common features, characteristics and peculiarities of the nation. Who are the Finns? The Finns nurture their national identity; they are attached to their land, customs and habits; they continue traditions inherited from their ancestors, actively nurturing the peculiarities of the Nordic way of life; and despite the climatic conditions, they spend a lot of time outdoors. They are practical, hardworking and active, and have a do-it-yourself (DIY) approach (Pantzar, 2018b). At home, they prefer to do everything themselves (for example, to build, renovate or repair a house), rather than to ask for help by hiring or purchasing a service. They are characterised by minimal and sustainable consumption. The Finns are members of a circular economy and sustainable consumption: they try to repair old, broken or damaged things, and give them new life; they do not rush to throw away old things and buy new ones. The Finns do not like to sell, but prefer to renovate, rebuild, reconstruct and repair their homes, and are spiritually closely associated with their homeland and sentimentally connected areas, places where they were born and raised. They respect the land of their parents and ancestors. It is important for Nordics to spend a lot of time in nature, to do simple household chores, and engage in physical activity daily. Respect for other people and nature, and respect for humanity, trust, law and safety, are considered the secret of Finnish happiness.

The Finns consider themselves as modest, restrained, hardworking and thoughtful people, who do not look back and never give up (Sinkkonen, 2013). 


\section{Birutė Strukčinskienè}

They are based on a traditional Finnish cultural ideology; the unique word for it is sisu.

\subsection{The Finnish sisu phenomenon}

What inspires the Finnish nation, what gives them inner strength and perseverance, what is that magic word sisu, why is the study of the cultural construct of sisu important? A. Duckworth mentions an article published in Time magazine in 1940, which claimed that the Finns have something they call sisu. That enigmatic sisu consists of courage, perseverance and strength, the ability to fight, and to fight hard with the desire to win (Duckworth, 2016). By the 1960s, Austin Goodrich was talking about sisu in a saga about the courage and idealism of Finland's struggle for independence (Goodrich, 1960). A. H. Hicks and O. Tokoi (1959) discussed the persevering sisu spirit and the sisu phenomenon in the autobiography of the first prime minister of Finland, Oskari Tokoi (Hicks, Tokoi, 1959). In 1991, P. S. Lander talked about the Finns with an ethnic script they were fashioning themselves, about the Finnish identity and sisu in a changing Europe (Lander, 1991). In 1994, W. R. Aho conducted a survey that questioned Finnish American respondents about their beliefs in sisu (Aho, 1994). K. Lucas (2002) dedicated her MA thesis to her grandfathers, two underground miners who lived lives of sisu. She remarked that sisu is a Finnish word that has been likened to qualities such as perseverance, determination, courage, inner determination, and something that surpasses fearlessness and extraordinary endurance (Lucas, 2002). M. Dahlgren and M. Nurmelin (2007) introduced the role of sisu in the Finnish lifestyle and culture. A. Pankalla and J. Gronska-Turunen (2010) examined the meaning of the Finnish cultural construct sisu (perseverance, courage, stubbornness, determination) through the paradigm of the cultural psychology of emotions (Pankalla, GronskaTurunen, 2010). S. Amato-Henderson et al. (2014) mentioned that sisu is a Finnish term loosely translated as endurance or resilience in the face of adversity (AmatoHenderson et al., 2014). According to J. V. Cohen (2018), sisu helps to develop the ability to keep fighting after most would quit (Cohen, 2018). In the study by J. Adamczewski and M. Obrebska (2018), sisu is used as a keyword approach, which helps to understand Finnish culture (Adamczewski, Obrebska, 2018). According to M. Etherington (2019), the concept of sisu became a Finnish notion

for describing the strong Finn, and a culture that displayed determination, grit, bravery, resilience, courage and resoluteness in the face of adversity (Etherington, 2019).

The word sisu is very special for Finns (Sinkkonen, 2013). E. Lahti (2014), in her comprehensive research on sisu, tried not only to summarise this cultural cons- 
truct in active research, but also to share the results with the global community, in order to transfer this good practice to other nations and other cultures (Lahti, 2014). The construct of Finnish culture known as sisu is used to describe an enigmatic force that helps to accept unbearable challenges, to surmount extraordinary obstacles, and to overcome mentally and physically difficult situations. It is like a mindset of action, a consistent and courageous approach to challenges that at first sight seem to be beyond human powers and abilities (Lahti, 2014; 2019). The Finnish word sisu is untranslatable. Roughly, it would mean power of will, determination and perseverance (Sinkkonen, 2013). K. Pantzar (2018) associates sisu with a sense of well-being, inexpensive and simple solutions that do not require special efforts, devices or expensive equipment, and this is available to many people regardless of time or budget constraints (Pantzar, 2018a). Sisu has the ability to withstand great stress. Sisu is based on the Finnish spirit, on striving resolutely to fight and win (Cohen, 2018). The essence of this Nordic approach is to take measures to improve one's mental and physical condition and well-being, to achieve a healthier and happier life. The goal of sisu is to turn challenges into opportunities (Pantzar, 2018b).

Sisu is a 500-year-old Finnish construct with a unique spirit and strength that allows people to endure hardship, despite feeling that they have already reached the limit of their physical or mental abilities. Sisu is what a person depends on when nothing is left. Sisu gives the last push when someone is forced to act (Velázquez, 2014). According to the ideology of the Nordic cultural construct, a sisu education is equally important for both men and women (Nylund, 2018).

Sisu is the ability to recover from repeated failures and persevere with the aim of achieving a goal. It is the motivation not only to take the first step, but also to encourage further progress. However, at what moments should sisu be used? For example, when you are outside your comfort zone (e.g. when you have six miles left to finish a marathon, but you feel you are lacking strength; you feel that you have done everything you can do to reach your goal, but you have not achieved it yet) (Lahti, 2014; Velázquez, 2014). E. Lahti from Finland has systematically described this construct as the phenomenon of universal latent energy within a person. The main results of her research reveal the perception of sisu as a reserve of inner strength that helps to cope with mentally or physically difficult situations through extraordinary actions (Lahti, 2014; 2019). People often face challenges in life that they have to overcome with courage and determination. In these situations, many people face resistance and a fear of enduring it. Facing moments when you feel you have reached the end of your potential and can see only an endless need for courage and perseverance to move forward requires a special inner strength to survive and overcome this challenge. 


\section{Birute Strukčinskienè}

Is this just a Finnish feature? Can anyone develop a resilient Finnish style and find their sisu? (Pantzar, 2018b). Finland is a pioneer of sisu, but this traditional ideology, approach, and way of life, this cultural construct, can be used by other people as well. It is a universal power with potential for all individuals. Sisu helps to understand the determinants of human resistance, the actions that lead to perseverance and resistance, and to understand how to strengthen perseverance through the use of sisu (Lahti, 2014). Sisu inspires people to persevere in the pursuit of goals, and to fight for success despite difficulties, even when it seems that the limits of human strength have already been reached. Perseverance, stamina, resilience, the ability to regain strength quickly, positive psychology, and energy reserves, are closely related to the phenomenon of sisu (Lahti, 2014; 2019; Pantzar, 2018a; 2018b).

Sisu has nothing to do with altruism, humanity or helping. Surplus actions and surplus activity are not related to $s i s u$. The essence of sisu is to survive. The essence of sisu in a practical context is expressed by bathing in cold water, using the power of a sauna, applying nature therapy, striving for happiness, engaging in health-enhancing physical activity and healthy nutrition, practising Nordic minimalism, achieving harmony between physical and mental activities, etc. Developing and building up sisu is a challenge for the individual, and at the same time a precondition for comprehensive health and harmony.

\subsection{Building up sisu}

Sisu is believed to be a flexible quality, and can be developed consciously. The majority of respondents of the sisu surveys said they were interested in educating and developing their sisu (Lahti, 2014; 2019). An issue like perseverance, not giving up in the face of a challenge, can be learnt (Pantzar, 2018a). The general results of the development of sisu, the accumulation of energy reserves, and the strengthening of perseverance, will and harmony, are associated with these nine components:

- Nature mindfulness.

- Positivity.

- Relaxation and recreation.

- Physical activity.

- Withdrawal/demarcation and stepping back.

- Burden reduction (task fragmentation).

- Leaving the comfort zone (little challenges).

- Experience transmission, spreading and radiating.

- Reward for completing a task. 
Nature mindfulness: interaction with nature, nature therapy and forest therapy. One of the key points for building up sisu is nature mindfulness. Interaction with nature, nature therapy and forest therapy are essential for the development of sisu. The gap between nature and naturalness, and the shift to artificial life, has destroyed the prevailing human symbiosis with the natural universe, pushing people into a state of constant tension, stress, fear and insecurity. The effects of nature on humans have many positive aspects. Nature 'removes' stress, allows us to relax, 'clears' thoughts, and allows you to be yourself. The connection with nature is important for people, for their spirit, health and harmony.

The quietest place in the world is said to be the Finnish forest. The relatively safe nature of Finland is famous for its soothing silence. Nature is a magnificent engine for growing Finnish sisu (Nylund, 2018). Touching the 'natural world' is important for a person, for his or her spirit, health and harmony (Pantzar, 2018a; $2018 \mathrm{~b}$ ). What today is called natural therapy and forest therapy, was and is a natural, innate experience for the Finns. A return to nature gives peace of mind, calms the soul, and inspires new challenges. Nature is a rest for the thoughts, an opportunity to be in silence. Listening to the sounds of the forest, the songs of the birds and the relaxing wind and water, helps to escape the noise, hurry, chaos, constant messages and clutter of modern urban life. You can have your favourite place in nature: in the forest, by water (the sea, a lake, or a river), a so-called 'own room', where you like to come and spend time. The Finns recommend resting in nature and watching it. For example, to find a picturesque place in nature, and to observe the environment in silence; a flying leaf, a bird, a butterfly, a cloud, mushrooms growing; to feel the wind on your face; to close the eyes and inhale, trying to associate smells with feelings and memories; to touch a tree and feel a connection with nature and plants (Nylund, 2018).

Positivity (don't give up!). Positivity is important and powerful. Analysing the effect that a compliment has, it has been observed that a compliment causes a person to stretch, smile and behave differently. Positivity clearly uplifts individuals. Positivity 'sets the overall tone of life in systems' (Hämäläinen et al., 2014). Positive thinking enables one not to give up (Lahti, 2019). A positive attitude can be developed consciously. Dispositional optimism, or the belief that good things will happen, influences everything, from lowering the sense of loneliness to increasing the tolerance of pain. Positivity is a key component of creativity, and both permanent happiness and short moments of pleasure help to 'solve insight puzzles' better. In addition, a good mood helps one to relax, and a relaxed brain is open to establishing a positive relationship and positive connections (Hämäläinen et al., 2014). Positive adaptation, positive 'refreshing' changes in an individual's life, and positive quality, are closely related to sisu and examples of success in 


\section{Birute Strukčinskienè}

Finnish history (Lahti, 2019). Positivity affects not only the individual himself, but also the people around him, and the systems with which he interacts. Everyone can be positive. Research shows that it is possible to learn to adopt the right mindset. Strategic optimism (not to be confused with overconfidence) can help to organise life, to believe that everything will be solved, and problems will not ruin a person's life (Hämäläinen et al., 2014).

Sisu encourages positive action, and inspires conventional forces to grow and break out of their boundaries. This way, sisu shows its obvious place in positive psychology ('the science of happiness') (Nylund, 2018). Self-exhaustion/self-destruction/self-devastation/self-deprecation and self-torture with negative thoughts, tiring thoughts, and a lack of positivity 'push' the individual into depression, sadness and despair. Annoying, frustrating or bothering yourself with negativity crushes self-esteem. According to K. Pantzar, negative thoughts pull a person down 'like a vortex' (Pantzar, 2018a). Communication with a positive person, positive activities, a positive attitude and thinking, a positive meeting, a conversation, a call or a letter, inspire a positive life, an ability to work, and to be creative and innovative. Positivity, a positive mental attitude, and mental, emotional and health promotion are essential for building up sisu.

Relaxation, rest and recreation. Rest, relaxation, recreation, the recovery of mental and physical strength, the harmony between work and rest, individual rest, and a balanced daily routine are important in building up sisu. An exchange between work and rest is necessary, because uninterrupted work destroys the mind, soul and body. A simple Finnish formula, eight hours of work, eight hours of rest/ leisure, and eight hours of sleep, helps to maintain a balanced, creative and resilient personality. Rest helps to build up energy reserves, and improves strength and perseverance.

Constant disturbances and interference, a passive lifestyle, and posture and vision problems force Finns to listen to their ancestral roots, and to distance and disconnect themselves from activity, work and endless tasks. Traditional weekend trips to the countryside and nature allow them to take a break from work and to relax. To be truly disconnected, to have time alone, and to embrace silence, help the Finns to enjoy peace of mind (Nylund, 2018).

The Finns believe it is necessary to spend time in private, to have time alone. It is advisable to find time every day to sit apart from others for 20 minutes (or at least five), and do nothing but simply breathe with closed eyes, to be with oneself and think about what is going on and what one is feeling. In this way, it is possible to concentrate and focus on oneself, and open the doors to one's inner strength, one's sisu (Nylund, 2018). An individual's rest/relaxation revives the strength, helps to find extra energy, and develops strength and perseverance. 
Physical activity. Physical activity and exercise help to strengthen health, endurance and perseverance, things that increase sisu (Pantzar, 2018a). Finnish researchers state that the best aspects of human existence are that we can think and move (Meri, 2019). Physical exercise and physical activity enhance physical, mental and social health, and reduce the mortality and morbidity rate; they reduce stress, psychological tension, anxiety and depression; they improve general health, the immune system, work capacity, physical fitness, well-being, mood and sleep; they promote self-confidence, and provide satisfaction (Strukcinskiene, Raistenskis, Sopagiene, Kurlys, Stasiuviene, Griskonis, Radziuviene, 2012; Strukcinskiene, Rasitenskis, Radziuviene, Strukcinskaite, 2018; Adaskeviciene, Strazdiene, 2013; Bule, 2018; Hale, Guan, 2015; Bentlage, Ammar, How et al., 2020; Burtscher, Burtscher, Millet, 2020; Dohrn, Kwak, Oja, Sjöström, Hagströmer, 2018; Hallal, Andersen, Bull, Guthold, Haskell, Ekelund, 2012; Booth, Laye, Lees, Rector, Thyfault, 2008). Excessive stress increases the risk of mortality from cardiovascular disease, and can cause mental health disorders. Exercise enhances the activity of brain cells. In addition, physical activity increases the branches of nerve cells and improves the memory (Meri, 2019). Physical activity increases perseverance and resilience, and helps to accumulate and store energy reserves and inner strength.

Withdrawal/demarcation and stepping-back. In sisu ideology, it is important to withdraw from factors or events that cannot be changed (e.g. illness, death, disability). Accepting events that cannot be influenced develops resilience and balance. In addition, it is important to distance oneself from 'what is not yours', from the roles, tasks, duties and responsibilities of strangers. A person cannot live the lives of other people, suffer the illnesses of others, or perform all their tasks. Isolation from strangers' problems increases stability, hardens the soul, cultivates self-control, and strengthens the spirit. This allows one to save energy and capacity, preserve mental health, and focus on one's own goals and results.

The ability to step back is important for the development of sisu. Stepping back is a necessary strength-saving factor. Excessive struggling is unnecessary and harmful. Not every battle has to be meaningless, especially if there is insufficient strength to win. A wise withdrawal is more important than an unnecessary waste of energy. Constructive sisu is not blind and obsessive, but flexible, adaptable and causal (Lahti, 2019). There are situations where, instead of fighting, it is better to accept a situation, and sometimes to be content with what one has (Lahti, 2019). To build up sisu, flexibility is important.

Task fragmentation (burden reduction). In sisu ideology, burden reduction, or splitting it into smaller fragments (fragmentation), enables one to 


\section{Birute Strukčinskienè}

achieve more, and makes it easier to attain the desired goal. Reducing an enormous challenge and splitting it into smaller parts facilitates the consistent achievement of the desired result.

Sisu is related to overcoming problems, discomfort and challenges. The sisu phenomenon emphasises the intensive performance of short-term tasks, rather than the immediate conquest of a long-term task, and focuses on large, overarching life goals (Lahti, 2019). A step-by-step approach to smaller tasks leads to the final result. According to E. Lahti (2014), perseverance in achieving a long-term goal can be considered a fixed quality. The sisu construct is a flexible quality when the goal is broken down and is achieved flexibly in parts (fragments) (Lahti, 2014).

Leaving the comfort zone (small challenges). Leaving the comfort zone in life is necessary (small challenges). Small challenges foster creativity, make life dynamic, encourage improvement, and make one seek solutions, act, and move forward. Comfort zones are beneficial, but challenges are needed in order to grow and improve. According to J. Nylund, 'Facing and overcoming challenges is key to fostering sisu' (Nylund, 2018, p. 94).

A comfort zone is a mental state in which the existence of the individual is prioritised. It is an environment where people usually spend their daily lives doing the things they do best. When an individual accepts challenges and activates his sisu, he can achieve amazing results.

However, accepting too complicated challenges can cause too high a level of stress; therefore, the anxiety associated with a challenge must be at a controlled level (Nylund, 2018). Moderate challenges, such as visiting a new area, trying out a new hobby, or performing an unusual or more complex task, could be an appropriate challenge. Efforts to learn new things (both in professional and leisure contexts) can also be an acceptable challenge.

Transfer of experience, dissemination, radiation. The transfer of experience and lifestyle is important to the sisu phenomenon. Other terms for this transfer are 'spreading', 'message transmission', 'dissemination' and 'radiation'. The sisu experience is passed down from generation to generation, and moves on in society by spreading horizontally.

The message of sisu must spread, inspire new family members, and connect relatives to act as communities. Parents and elders share their experience and lifestyle, and show, teach and encourage children and young people to build up sisu; they teach them how to concentrate on goals, how to develop and accumulate extra strength, energy and inner strength, how to develop perseverance and resilience, and how to become healthy, harmonious and balanced. Parents are role models for children. Children learn how to overcome challenges from parents and other fa- 
mily members. Parents encourage children to achieve goals, they encourage them, support them, and help them form positive attitudes. Teachers have a similar role to play, but the family example is a priority. Sisu can become a challenge for parents themselves if they try to make tasks easier for children and deprive children of the opportunity to learn from difficulties and challenges. Sisu is a cultural heritage that spreads in society. Sisu emerges in society, and is further radiated to society.

Reward for completing a task. Is it necessary to thank yourself, to reward yourself, for completing a task? On one hand, the successful achievement of a goal is in itself the greatest reward. The joy of victory in work done, the result achieved, is a self-reward for the effort put into it. On the other hand, overcoming difficulties and completing a task can be rewarded by yourself. It may be time to do what you love. For instance, going to a concert, a movie, a weekend with family, with children, leisure time with friends, time spent with pets, a walk in the woods or by the sea. A special prize for a child can also be a reward for effort and hard work.

In summary, it could be said that sisu is a phenomenon of Finnish culture, an example of an original lifestyle, or a concept of traditional ideology. It is a construct of Nordic culture, an expression of national identity, and a unique way of life. This phenomenon of Nordic culture has existed in the Finnish nation for over 500 years. The Nordic cultural construct, Finnish sisu, can be used for the development of a healthy, harmonious and balanced personality. Sisu is a consistent and courageous approach to challenges, which at first glance seems to exceed human powers and capabilities. The sisu phenomenon inspires to persevere in the pursuit of goals, to fight for success despite difficulties, even when it seems that the limits of human endurance have already been reached. It is a reserve of energy to overcome challenges; it is courage and perseverance, the mobilisation and manifestation of additional forces to achieve a goal. Efforts to accumulate an additional reserve of energy, to develop, to build up sisu, strengthen physical and mental health. The development of constructive sisu helps to increase perseverance, resilience, inner strength and endurance, to strengthen health and harmony, and enables a person to develop a balanced, persevering and resilient personality. Sisu can be developed consciously. The following are important components to build up sisu for the development of perseverance and inner strength: nature mindfulness, physical activity, positivity, rest and recreation, stepping back and demarcation, task fragmentation, leaving the comfort zone, the transfer of and spreading experience, and a reward for achieving a goal.

\section{Conclusions}


A healthy and sustainable society, a balanced personality and a healthy lifestyle are important public health research issues that are particularly relevant during the pandemic and strict lockdown. The Nordic cultural construct used in Finland called sisu, a kind of lifestyle, a kind of ideology of life, helps one not to give up, to keep a balance, and to develop a strong and healthy society. It is appropriate to apply the experience of Finnish culture to the development of a healthy and harmonious personality through the phenomenon of sisu. Sisu is a kind of perseverance and inner strength. Important elements to build up sisu are: nature mindfulness, nature therapy and forest therapy, positivity, rest, relaxation and recreation, physical activity, withdrawal and stepping-back, task fragmentation, leaving the comfort zone (small challenges), the transfer of, spreading and radiating experience, and a reward for achieving a goal.

\section{Acknowledgments}

Sincere thanks for inspiration, insights, kind help, support and valuable discussions go to colleagues and friends in Finland, and in particular to Prof. Dr Seppo Meri, Prof. Dr Tarja Suominen, Mr Yrjö Heimonen, Assoc. Prof. Dr Minna Koskimäki, and Assoc. Prof. Dr Jari Kylmä. Sincere thanks for the English editing go to Prof. Dr Susan Robbins.

\section{References}

Adamczewski, J., Obrebska, M. (2018). Sisu - emocja kulturowa, schemat poznawczy czy słowo klucz do tożsamości Finów? Annales universitatis Mariae Curie-Sklodowska Lublin-Polonia, Vol. 31 (4), p. 51-64.

Adaskeviciene, E., Strazdiene, N. (2013). Children's health-enhancing physical activity development. Klaipeda: Klaipedos universiteto leidykla.

Aho, W. R. (1994). Is sisu alive and well among Finnish Americans? In M. G. Karni, J. Asala (eds.). The best of Finnish Americana, p. 196-205. Iowa City, IA: Penfield Press.

Aleknavičienė, J., Pocienė, A., Šupa, M. (2020). Kaip parašyti mokslinį rašto darbą? Vilnius: Vilniaus universiteto leidykla.

Amato-Henderson, S., Slade, D., Kemppainen, A. (2014). Measuring Sisu: Development of a tool to measure mental toughness in academia. Proceedings of the Human Factors and Ergonomics Society Annual Meeting, Vol. 58(1), p. 1434.

Bentlage, E., Ammar, A., How, D., Ahmed, M., Trabelsi, K., Chtourou, H. ir kt. (2020). Practical Recommendations for Maintaining Active Lifestyle during the COVID-19 Pandemic: A Systematic Literature Review. International Journal of Environmental Research and Public Health, Vol. 17(17), p. 6265.

Booth, F. W., Laye, M. J., Lees, S. J., Rector, R. S., Thyfault, J. P. (2008). Reduced physical activity and risk of chronic disease. The biology behind the consequences. European Journal of Applied Physiology, Vol. 102(4), p. 381-390.

Böök, M. L., Mykkänen, J. (2019). Finnish Mothers' and Fathers' constructions of and emotions in their daily lives. Scandinavian Journal of Educational Research, Vol. 63(3), p. 412-426.

Brueggeman, M. A. (2008). An outsider's view of beginning Literacy in Finland: Assumptions, lessons learned, and sisu. Literacy Research and Instruction, Vol. 47(1), p. 1-8.

Bule, M. (2018). EUROPREV Guide on promoting health through physical activity. Kaunas: Vitae Litera. 


\section{BUILDING UP SISU, A NORDIC CULTURAL CONSTRUCT FOR THE COMPREHENSIVE...}

Burtscher, J., Burtscher, M., Millet, G. P. (2020). (Indoor) isolation, stress and physical inactivity: Vicious circles accelerated by Covid-19? Scandinavian Journal of Medicine \& Science in Sports. Vol. 30(8), p. 1544-1545.

Cohen, J. V. (2018). Sisu - the ability to keep fighting after most would quit. JAMA Oncology, Vol. 4(10), p. 1329.

Dahlgren, M., Nurmelin, M. (2007). A survival guide to Finnish. Sauna, Sisu \& Sibelius. Helsinki: Yrityskirjat.

Dohrn, I. M., Kwak, L., Oja, P., Sjöström, M., Hagströmer, M. (2018). Replacing sedentary time with physical activity: A 15-year follow-up of mortality in a national cohort. Clinical Epidemiology, Vol. 10, p. $179-186$.

Duckworth, A. (2016). Grit: The power of passion and perseverance. New York: Scribner.

Dunne, L. (2017). Lagom: The Swedish art of balanced living. London: Octopus Publishing Ltd.

Etherington, M. (2019). Pride in Education: A Narrative study of five Finnish Schoolteachers. SAGE Open, p. $1-15$.

Goodrich, A. (1960). Study in SISU: Finland's fight for independence. New York: Ballentine Books.

Hale, L., Guan, S. (2015). Screen time and sleep among school-aged children and adolescents: a systematic literature review. Sleep Medicine Reviews, Vol. 21, p. 50-58.

Hallal, P. C., Andersen, L. B., Bull, F. C., Guthold, R., Haskell, W., Ekelund, U. (2012). Global physical activity levels: Surveillance progress, pitfalls, and prospects. Lancet, Vol. 380, p. 247-257.

Hämäläinen, R. P., Jones, R., Saarinen, E. (2014). Being better better: Living with systems intelligence. Helsinki: Aalto University Publications, Nord Print.

Helliwell, J. F., Layard, R., Sachs, J., De Neve, J. E. (eds). (2021). World Happiness Report 2021. New York: Sustainable Development Solutions Network.

Hicks, A. H., Tokoi, O. (1959). Sisu: "Even through a stone wall". The Autobiography of Oskari Tokoi. International Affairs, Vol. 35(1), p. 79-80.

Lahti, ${ }^{1}$ E. (2014). Above and beyond perseverance: An exploration of Sisu. Doctoral Dissertation. Philadelphia: University of Pennsylvania.

Lahti, ${ }^{2}$ E. (2019). Embodied fortitude: An introduction to the Finnish construct of sisu. International Journal of Wellbeing, Vol. 9(1), p. 61-82.

Lander, P. S. (1991). Finnish identity in a changing Europe. Ethnos, Vol. 56(3), p. 242-255.

Lucas, K. (2002). Occupational narrative in a blue-collar community: Rejecting the dominant discourse with stories of "sisu”. Master Thesis. West Lafayette, IN: Purdue University.

Meri, S. (2019). Lenkille ja lukemaan! Lääketieteellinen Aikakauskirja Duodecim, Vol. 135(5), p. 419.

Ministry of Social Affairs and Health ${ }^{1}$. (2020). Finland is a gender equality Pioneer. Helsinki, Finland. Available on line: https://stm.fi/en/finland-is-a-gender-equality-pioneer.

Ministry of Social Affairs and Health ${ }^{2}$. Gender equality is a core value in Finland. Helsinki, Finland. https://stm. fi/en/140-years-of-gender-equality.

Nylund, J. (2018). Sisu: The Finnish art of courage. London: Gaia, Octopus Publishing Group Ltd.

Pankalla, A., Gronska-Turunen, J. (2010). Sisu - Finnish cultural emotion and its myth analysis according to $\mathrm{r}$. Shweder's concept. Roczniki Psychologiczne, Vol. 13 (2), p. 29-53.

Pantzar, ${ }^{1}$ K. Finding Sisu: In search of courage, strength and happiness the Finnish way. London: Hodder\& Stoughton Ltd.

Pantzar, ${ }^{2}$ K. (2018). The Finnish way: Finding courage, wellness, and happiness through the power of sisu. New York: TarcherPerigee.

Sinkkonen, J. (2013). The land of sauna, sisu and Sibelius - an attempt at a psychological portrait of Finland. International Journal of Applied Psychoanalytic Studies, Vol. 10(1), p. 49-52.

Strukcinskiene, B., Rasitenskis, J., Radziuviene, R., Strukcinskaite, V. (2018). Healthy lifestyle in children and teenagers: Focus on physical activity. Klaipeda: Druka.

Strukcinskiene, B., Raistenskis, J., Sopagiene, D., Kurlys, D., Stasiuviene, D., Griskonis, S., Radziuviene, R. (2012). Child physical activity and health. Klaipeda: Jokužio leidykla-spaustuvè.

Taramaa, R. (2007). Stubborn and silent Finns with "sisu” in Finnish-American literature: An imagological study of Finnishness in the literary production of Finnish-American authors. Oulu: Oulu University Press.

Velázquez, M. (2014). Sisu: Beyond perseverance. Available on line: https://positivepsychologynews.com/news/ marta-velazquez/2014121530618.

Wiking, ${ }^{1}$ M. (2017). The little book of Hygge: Danish secrets to happy living. The Happiness Research Institute, Copenhagen. New York: HarperCollins Publishers.

Wiking, ${ }^{2}$ M. (2017). The little book of Lykke: The Danish search for the world's happiest people. London: Octopus Publishing Ltd. 
Birute Strukčinskienè

Birutė Strukčinskienė - professor, doctor of Biomedicine Sciences (Public Health) at the Faculty of Health Sciences, Department of Public Health, Klaipeda University, Lithuania.

E-mail: birute.strukcinskiene@ku.lt 